\title{
AL-IQTISHADIYAH
}

Jurnal Ekonomi Syariah dan Hukum Ekonomi Syariah

E-ISSN: 2621-0274; P-ISSN: 2442-2282

Volume 5, Nomor 1, Juni 2019

\section{ENTITAS BUDAYA SEBAGAI KARAKTERISTIK ETOS KERJA DALAM PESPEKTIF EKONOMI SYARIAH}

\author{
Akhmad Hulaify \\ Fakultas Studi Islam, Universitas Islam Kalimantan Muhammad Arsyad al-Banjari, Indonesia. E-mail: \\ hulaify@gmail.com
}

\section{ARTICLE INFO}

\section{Kata Kunci:}

Budaya; Entitas; Ekonomi Syariah; Etos Kerja; Karakteristik

\section{ABSTRAK}

Kajian ini merupakan kajian fenomenologi yang berusaha menelusuri bagaimana sebenarnya realita budaya yang dalam konteks teoritis berusaha membangun persepsi kerja yang profesional dan berkualitas. Keberadaan budaya yang melekat pada diri individu khusunya seorang muslim tentunya tidaklah hal sulit dalam membangun persepsi profesional dan berkualitas, mengapa demikian. Hal tersebut tentunya sebagai seorang muslim mempunyai karekter yang sejalan dengan kehendak agama yaitu segala sesuatu perbuatan dikatenakan niat tulus kepada Allah. Hasil kajian menunjukkan bahwasanya entitas budaya dalam membangun etos kerja dalam perspektif Ekonomi Syariah dengan melihat beberapa faktor yaitu al-Shalah, al- Itqan, alIhsan, al-Mujahadah, dan Tanfus. Lima karekter tersebut merupakan gambaran yang bisa menjadi acuan dalam melihat potensi budaya kerja sebelum seorang individu masuk dan bekerja dalam sebuah perusahaan. Perusahaan tentunya juga harus berupaya memupuk karakter tersebut demi tercapainya misi, misi dan tujuan perusahaan.

\section{Pendahuluan}

Pembentukan budaya tentunya bukan sebuah perkara sederhana dalam kehidupan, terlebih lagi dalam dunia kerja. Banyak teori berusaha untuk membentuk karekter para pelaku kerja. Teori tersebut berusaha dituangkan dalam dunia realita yang mempunyai keberagaman karakter dan budaya masyarakat. Ada yang mampu mengaplikasikannya dalam dunia kerja, namun tidak sedikip pula yang "kebablasan" dalam merefleksikannya. Dari sekian banyak kajian tentunya permasalahan tersebut tidak lah sampai disitu dalam rangka mengungkap dan menjelaskan penomena kerja terlebih lagi kita bandingkan dengan pola dan budaya masyarakat sekarang yang sudah bergeser dari yang mula-mula berorientasi kepada penemenuhan kebutuhan hidup dalam rangka ibadah berbalik kepada bernilai uang yang semata-mata dunia.

Kondisi tersebut tentunya menarik untuk dicermati dan dikaji kembali. Mengapa penomena tersebut terjadi dan berulang secara terus menerus. Islam sebagai sebuah agama dituntunt untuk terus berevolusi dalam mengkaji dan menemukan solusi dalam rangka menyelamatkan umat manusia di dunia dan akhirat. Solusi tersebut 
tentunya tidaklah datang sesederhana yang kita pikirkan sebagaimana dijelaskan dalam Al Quran Surah al-Ra'd Ayat 11:

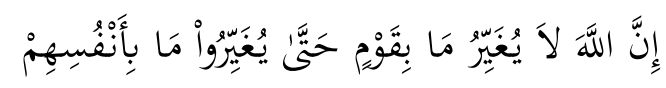

Artinya: "...Sesungguhnya Allah tidak merobah Keadaan sesuatu kaum sehingga mereka merobah keadaan..."

Dalam kajian tafsir Qurais Shihab menjelaskan terkait ayat diatas bahwa Demikian pula, Allah tidak akan mengubah nasib suatu bangsa dari susah menjadi bahagia, atau dari kuat menjadi lemah, sebelum mereka sendiri mengubah apa yang ada pada diri mereka sesuai dengan keadaan yang akan mereka jalani. ${ }^{1}$

Tentunya tidaklah jauh berbeda ketika dalam kehidupan bahwa seseorang tersebut tidak berusaha untuk melakukan yang terbaik tentunya ia tidak akan mendapatkan yang terbaik sebagaimana harapannya. Sesuatu yang baik dalam hal ini pola dan standar untuk menjadi acuan dalam ranfka mewujudkan dunia kerja yang membawa berkah dan manfaat di dunia dan akhirat perlu sebuah standar capaian kinerja bagi pelaku kerja.

Beranjak dari kajian tersebut tentunya tulisannya ini berusaha mengkolaborasi dan meramu antara teori dan ralitas kehidupan dalam ranga membedah standar kerja dalam rangka pembentukan budaya kerja dalam perspektif Ekonomi Syariah. Kajian ini, dilakukan melalu beberapa observasi baik dari media maupun dari literaturliteratur yang ada dan relevan dengan pembahasan yang akan dibahas dalam tulisan ini.

\section{Pembahasan}

\subsection{Konsep dasar Budaya dan Kerja dalam Kajian Islam}

Budaya menurut akar katanya mempunyai makna pikiran (akal budi) atau hasil dari adat istiadat baik dalam kontek beradap/maju atau sesuatu yang sudah menjadi kebiasaan yang sudah sukar diubah.

Selo Soemardjan dan Soelaiman Soemardi mengartikan kebudayaan sebagai semua hasil karya, rasa dan cipta masyarakat. Karya meliputi produk teknologi dan kebendaan lainnya. Rasa meliputi jiwa manusia yang selaras dengan norma dan nilai sosial. Cipta meliputi kemampuan kognitif dan mental untuk mengamalkan apa yang diketahuinya.

Kemudian L. Kroeber dan Clyde Kluckhohn mendefinisikan kebudayaan sebagai keseluruhan pola-pola tingkah laku dan pola bertingkah laku, baik secara ekslisit atau pun implisit yang diperoleh dan diturunkan melalui simbol sehingga akhirnya membentuk sesuatu yang khas dari kelompok masayrakat tertentu.

\footnotetext{
${ }^{1}$ https://tafsirq.com/13-ar-rad/ayat-11\#tafsir-quraish-shihab diakses 21 Januari 2019
} 
Dari beberapa pendapat tokoh budaya dapatlah ditarik sebuah kesimpulan bahwa Budaya merupakan hasil dari sebuah proses aktivitas baik pikiran, pekerjaan dan cipta rasa kelompok masyarakat yang dituangkan dalam kehidupan sehari-hari.

Suatu budaya memiliki nilai dan juga karakteristik tertentu. Mengacu pada pengertian budaya di atas, adapun ciri-ciri suatu budaya adalah sebagai berikut:

1. Budaya dapat menyimbolkan suatu suku atau daerah tertentu.

2. Budaya harus melalui proses belajar dan bukan suatu bawaan.

3. Budaya bisa diwariskan dari generasi ke generasi.

4. Budaya bisa disebarkan melalui komunikasi ke individu, kelompok, maupun ke generasi berikutnya.

5. Budaya sifatnya dimanis karena dapat berubah dari waktu ke waktu.

6. Budaya bersifat selektif dan menampilkan pengalaman dan pola tingkah laku manusia.

7. Unsur-unsur budaya dapat saling berkaitan satu sama lainnya.

8. Manusia cenderung mengklaim budayanya adalah yang terbaik.

9. Budaya dapat berubah karena adanya proses globalisasi.

Sebelum lebih dalam kita bahas tentang budaya, ada beberapa indikator utama dalam menentukan katekteristik budaya, dengan demikian dapat di kalisifikasikan bahwa budaya organisasi ke dalam empat tipe dasar:

1. Control culture. Dimana budaya impersonal nyata yang memberikan perhatian pada kekonkretan (jelasa dan menyeluruh pada sebuah objek) yang mana berpengaruh pembuatan keputusan yang melekat dengan analsis yang kuat pada orientasi masalah dan sudut pandang yang natural. ${ }^{2}$

2. Collaborative culture. Mengacu pada realitas individu dimana pengambilan keputusan yang dilakukan bersifat people-driven, organic dan informal. Dimana interaksi serta peran serta sebagai sebuah elemen pokoknya.

3. Competence culture. Budaya individu berlandaskan kepada kompetensi diri, dimana mempunyai tolak ukur terhadap potensi, alternatif pilihan yang besifat kreatif dan teoretis. Tipe budaya seperti ini mempunyai kecendrungan memiliki standar untuk meraih sukses yang lebih tinggi ${ }^{3}$.

4. Cultivation culture. Budaya ini mempunyai kemungkinan bahwa seorang individu mampu memperoleh inspirasi.

Sebuah budaya tidak terlahir dengan sendirinya melainkan melalui beberpa tahapan baik yang disengaja maupun tidak disengaja. Budaya yang tidak disengaja adalah budaya yang terlahir dikarenakan oleh rutinitas yang dilakukan secara terus menerus

\footnotetext{
2 Edy Sutrisno, 2010, Budaya Organisasi, Jakarta: Prenamedia Grup, hal.8.

${ }^{3}$ Alan R. Nankervis, 1996, Strategic Human Resource Manajemen, Melbourne: Nelson, hal. 56.
} 
misalnya bertutur kata, dimana komunikasi merupakan sebuah kebutuhan maka ia dilakukan secara terus menerus dan akhirnya membentuk bahasa/tutur kata. Sedangkan yang dilakukan secara sengaja adalah sebagaimana contoh diatas bahwa tutur kata merupakan sebuah komunikasi yang menjadi kebutuhan namun dalam prosesnya ada yang menghendaki bahwa tutur kata itu ternyata ada yang baik dan ada yang tidak. Dimana sifat dasar manusia berasumsi bahwa tutur kata tersebut harus lah baik. Maka dilakukan pembiasaan dengan menggunakan tutur kata yang baik. Segingga membentuk tuturkata yang sopan dan baik.

Proses terbentuknya suatu kebudayaan dipengaruhi oleh banyak faktor, baik itu faktor pendorong maupun faktor penghambat. Sesuai dengan pengertian budaya, berikut ini adalah beberapa faktor tersebut:

1. Faktor Pendorong Terjadinya Budaya

a. Niat masyarakat untuk melestarikan budayanya.

b. Adanya gererasi penerus yang mau meneruskan suatu budaya. ${ }^{4}$

c. Adanya rasa cinta terhadap budaya di dalam diri manusia.

d. Keinginan masyarakat untuk menjaga kelestarian suatu budaya agar tidak hilang.

e. Terjadinya perubahan lingkungan hidup yang mendukung berkembangnya suatu budaya.

2. Faktor Penghambat Terjadinya Budaya

a. Masuknya budaya asing yang kemudian menggeser eksistensi budaya lokal.

b. Masyarakat tidak memiliki keinginan untuk melestarikan suatu budaya.

c. Generasi penerus yang sudah tidak perduli dengan keberadaan suatu budaya.

d. Adanya anggapan bahwa budaya tertentu sudah kuno sehingga tidak ada keinginan untuk melestarikannya.

Dengan pendekatan badaya akan mengantarkan kita dalam sebuah kesimpulan dimana sekelompok masyarakat akan berbudaya jika pembiasaan terus dilakukan secara konsisten dan mengikat. Konsistensi tersebut tentunya perlu penjelasan mengapa harus dilakukan secara terus menerus disinilah peran adat dalam hal memberikan sebuah kesimpulan bahwa yang dilakukan tersebut mengandung unsur manfaat dan kebaikan untuk semua.

Ketika sebuah budaya sudah menjadi identitas dalam kehidupan masyarakat tentunya akan sangat mudah kita mengenali karekter mereka. Dengan demikian akan memudahkan kita dalam rangka untuk menyatu dengan kondisi mereka. Namun dalam hal tersebut yang perlu diperhatikan adalah agar kita tidak ikut

\footnotetext{
${ }^{4}$ Ibid, hal.18
} 
menyatu dengan hal-hal yang bersifat menghilangkan identitas keberadaan kita dalam budaya tersebut.

Sebagaimana dalam pembahasan kita saat ini bahwa sanya ketika kita mengenali budaya kerja seorang karyawan (kompetensi sumberdaya manusia) akan lebih mudah kita menempatkan pada bidang yang sesuai dengan keadaannya dan itu merupakan salah satu metode pendekatan dalam rangka meningkatkan produktifitas kerja dalam sebuah perusahaan.

Islam sangat menekankan unsur profesional dalam budaya kerja. Mengapa sampai sejauh itu Islam menjelaskan konsep tersebut. Hal itu sebagaimana penjelasan dalam sebuah hadits terkait dengan profesional kerja seseorang.

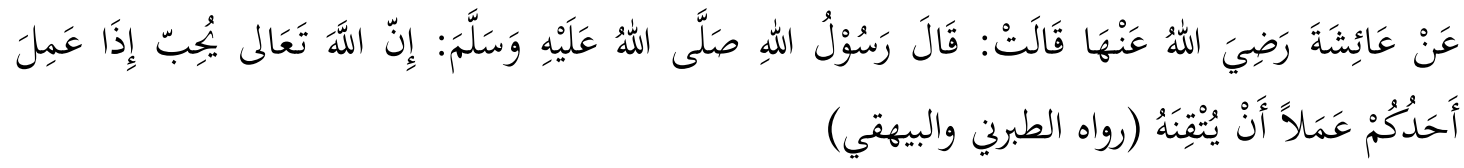

Artinya: Dari Aisyah r.a., sesungguhnya Rasulullah s.a.w. bersabda: "Sesungguhnya Allah mencintai seseorang yang apabila bekerja, mengerjakannya secara profesional". (HR. Thabrani, No: 891, Baihaqi, No: 334).

Melihat realita yang terjadi terkait dengan budaya yang tidak sengaja terbentuk akibat kesalahan dalam memaknai bahwa Islam mengajarkan sifat "tolong menolong" dalam kebaikan dalam kebaikan" sebagai mana dalam hadit yang diriwayatkan oleh Anas bin Malik, diceritakan bahwa ada seorang sahabat yang meminta bantuan kepada Nabi. Nabi memberi bantuan kepada sahabat itu, tetapi kemudian ia meminta lagi. Nabi memperingatkan sahabat itu dan mengajarkannya supaya ia tidak selalu meminta, mencari belas kasihan orang lain. Karena sesungguhnya tangan di atas atau memberi adalah lebih baik dari tangan di bawah yang meminta.

Memberi bantuan kepada sesama umat manusia yang membutuhkan dan sesuai dengan ajaran agama, adalah merupakan suatu perbuatan yang sangat baik dan terpuji. ${ }^{5}$ Islam menetapkan syarat-syarat bagi orang yang boleh meminta bantuan. Diantaranya; (1) orang yang memiliki tanggungan, bisa berupa denda atau tanggungan lainnya. (2) orang yang harta bendanya tertimpa musibah sehingga musnah. Dan (3) orang yang sangat membutuhkan. (HR. Muslim)

Penjelasan di atas tentunya menjadi bahan kajian kita terkait bahwa manusia harus memiliki iman dan takwa yang sempurna, kemudian harus beretos kerja tinggi dan mengarah pada profesionalisme. sehingga keberdaannya di dunia ini akan memberikan makna, turut serta dalam membentuk peradaban yang dicita-citakan Islam dan melahirkan teori dan karya besar demi kebaikan hidup di dunia dan di akhirat.

\footnotetext{
${ }^{5}$ Yusuf Al Qardhawi, 2006, Pesan Nilai dan moral dalam Perekonomian Islam, Jakarta: Robbani Press. hal. 24
} 


\subsection{Entitas Budaya sebagai Karakteristik Etos Kerja dalam Pespektif Ekonomi Syariah}

Etentittas budaya adalah satu kesatuan karekter yang di dalamnya terkandung nilai, pembimbing, kepercayaan, pengertian, norma, falsafah, etika, serta cara berpikir. Sehingga budaya yang tumbuh dan berkembang di suatu lingkungan, mempunyai pengaruh sangat besar kepada pembentukan pribadi yang tumbuh dilingkungan tersebut.

Dalam setiap lingkungan dimana seseorang tinggal mempunyai entitas budaya yang dibuat secara sadar maupun tidak oleh para pendahulu dalam konteks ini yaitu nenek moyang dan kemudian diturunka generasi ke generasi secara turun termurun dan kemudian dianut dan dilestarikan. ${ }^{6}$ Kondisi tentunya menjadi acuan kita untuk membedah entitas budaya dalam etos kerja dalam perspektif Ekonomi Syariah yang kemudian berorientasi kepada produktivitas ekonomi manusia.

Perusahaan merupakan sebuah lembaga tersesun dari banyak karyawan dimana setiap individu yang mempunyai dari latar belakang yang berbeda, baik agama, pendidikan, lingkungan, dst. Dengan demikian dapat disimpulkan bahwa sebuah perusahaan terdiri dari individu dengan katekter bawaan serta latar belakang yang berbeda-beda.

Beranjak dari penjelasan tersebut di atas muncul pertanyaannya, sanggupkan individu yang ada di dalam perusahaan tersebut untuk mencapai satu tujuan yang di inginkan perusahaan dengan iklim saling memahami, tolong menolong, serta saling mengerti dan memahami antar individu tersebut?

Perusahaan tidak lah jauh berbeda dengan lingkungan dimana tempat tinggal tentunya memiliki budaya yang dirumuskan oleh para pendiri serta top management dan kemudian dipahami serta dianut oleh para komponen dalam perusahaan.

Seorang karyawan perusahaan tentunya dituntut untuk memiliki skill, kreativitas yang tinggi, kecerdasan yang mampu motivasi kredibilitas agar perusahaan mudah dalam mencapai tujuannya dan nantinya mampu mensejahtrakan karyawaanya. Namun unsur-unsur tidak akan maksimal manfaatnya apabila setiap karakter budaya karyawan tidak sama dalam sebuah perusahaan. Dengan budaya yang sama tentunya akan membentuk pola pikir serta persepsi yang sama terhadap nilai serta kepercayaan yang mampu memfasilitasi karyawan dalam memahami bagaimana yang seharusnya dalam berperilaku kerja di perusahaan dimana mereka bekerja.

Kesatuan budaya dalam sebuah perusahaan dapat menjadikan perusahaan mencapai tujuan dan kesuksesannya. Untuk mewujudkan budaya perusahaan secara maksimal, maka diperlukan penanaman nilai-nilai kepada karyawan secara konsisten dan bersama. Rasa kebersamaan untuk menganut dan menjadikannya budaya atau nilainilai dalam menciptakan rasa persatuan serta percaya pada masing-masing karyawan. Bila kondisi ini telah menjadi iklim dalam bekerja, maka secara otomatis

\footnotetext{
${ }^{6}$ Stepen Robins, 1999, Perilaku Organisasi, Konsep, Kontroversi, Aplikasi, Alih Bahasa Hadyan Pujatmika, Jakarta: PT.Prenhallindo, hal. 32.
} 
akan menciptakan lingkungan kerja yang efektif, efesien dan kondosif. Dengan model lingkungan seperti tersebut tentunya dapat membangun jiwa kreativitas serta komitmen yang tinggi dari karyawan yan nantinya mampu menciptakan perubahan serta membawa ke arah yang lebih baik bagi perusahaan.

Secara umum dapat kita amati bahwa perusahaan-perusahaan yang ada dunia dengan predikat mapan dan sukses yaitu perusahaan dengan budaya kerja yang baik. Kemudian budaya kerja yang baik disini adalah dimana seluruh komponen yang ada di perusahaan mengamalkan dan menjiwai nilai atau norma yang telah sepakati dan ditetapkan secara bersama sebagai suatu budaya dan menjadi komitmen bersama tanpa melihat kearakter pada pribadi masing-masing karyawan.

Namun tidak sedikit kendala dalam menegaskan bagaimana budaya yang harus dianut oleh perusahaan sehingga menyulitkan karyawan dalam memahaminya. Oleh karana itu diperlukan sebuah pernyataan yang mampu untuk memanifestasikan budaya yang seharusnya perusahaan lakukan dalam konteks lebih spesifik dan sejalan dengan tujuan perusahaan.

Pernyataan tersebut diatas dapat tuangkan melalui sebuah perumusan pada pernyataan visi serta misi. Dengan kalimat yang singkat, pernyataan visi serta misi dapat menggabarkan unsur etika, nilai, prinsip, tujuan, serta strategi sebuah perusahaan. ${ }^{7}$ Apa yang tertulis pada pernyataan visi serta misi perusahaan merupakan sebuah cara yang paling efektif untuk memahami budaya sebuah perusahaan serta memudahkannya dalam mengimplementasikan metode-metode dalam pencapaian tujuan sebuah perusahaan.

Mengkaji hasil penelitian yang dilakukan oleh Prof. DR. John Kottler dan Prof. DR. Janes Heskett sebagai pakar di Harvard Business School, bahwa terdapat korelasi yang positif di antara penerapan budaya pada sebuah perusahaan terhadap prestasi bisnis perusahaan yang dicapai pada jangka waktu yang cukup panjang.

Dengan demikian bahwa bahwa budaya pada sebuah perusahaan mempunyai peranan penting untuk membangun sebuah prestasi serta produktivitas kerja karyawan dan akhirnya berdampak kepada keberhasilan. Oleh karena itu penitng menetapkan sebuah komitmen terhadap penerapan budaya perusahaan.

Terlepasa dari penjelasan diatas, sebuah budaya kerja bagi umat Islam pada Indutstri 4.0 saat ini, dimana banyak perusahaan yang mengadopsi budaya asing dikarenakan adanya asumsi bahwa hal tersebut begitu maju serta berkembang. Pada dasarnya budaya asing belum tentu selamanya mengandung unsur negatif mapun positif, budaya asing sah-sah saja untuk diadopsi dengan catatan bahwa budaya tersebut telah sesuai dengan aturan Islam. Sebagai contoh bahwa budaya yang menekankan kepada penghargaan terhadap waktu serta ketepatan dalam pemenuhan sebuah janji, hampir selalu dianggap bersumber dari budaya asing, akan tetapi model tersebut merupakan bagian dari aturan dan ajaran Islam.

\footnotetext{
${ }^{7}$ H.A.P Tilaar, 1997, Pengembangan Sumberdaya Manusia Dalam Era Globalisasi:Visi, Misi dan Proggram Aksi Pendidikan dan Pelatihan Menuju 2020, Jakarta :Grasindo, hal. 19.
} 
Sebagai contoh budaya kerja yang diterapkan pada sebuah institusi Perusahaan yang mempunyai prinsif syari'ah yang mengutamakan karekater akhlak mulia dimana yang didalamnya ada sifat Shiddiq, Tabliq, Fathanah, Amanah, serta Istiqomah.

a. Shiddiq mengandung makna kejujuran dimana segala perbuatan baik dalam ucapan dan perbuatan selalu berdasarkan ajaran and tutunan Islam. Tidak ada perbedaan serta pertentangan yang disengaja antara ucapan dan perbuatan. Oleh karena itu, Allah memerintahkan orang-orang yang beriman untuk senantiasa memiliki sifat shiddiq dan menciptakan lingkungan yang shiddiq. Firman Allah at-Taubah: 119.

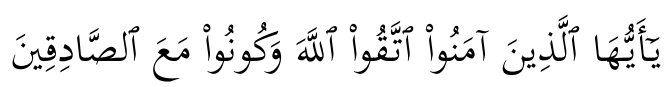

Artinya: "Hai orang-orang yang beriman bertakwalah kepada Allah, dan hendaklah kamu bersama orang-orang yang benar."

Dalam dunia kerja, kejujuran diwujudkan dalam bentuk sebuah kesungguhan serta ketepatan, baik dalam hal janji, waktu, pelayanan serta pelaporan, segala sesuatu dituangkan dalam yang sebenarnya tanpa ada hal yang ditutupi serta kemudian kalaupun ada kesalahan akan diperbaiki secara konsisten, kemudian menjauhkan diri ketidak jujuran baik kepada diri, teman sejawat, perusahaan maupun mitra kerja.

b. Tabliq, mengandung arti memberikan ajakan serta sekaligus memberikan gambaran kepada orang lain dalam rangka melaksanakan sesuatu sesuai dengan ketentuan-ketentuan ajaran Islam baik dalam kehidupan sehari-hari. Tabliq yang diapklikasin dengan wujud hikmah, kesabaran, argumentatif, dan persuasif tentunya akan mempererat hubungan kemanusiaan dalam sebuah dunia kerja.

c. Fathanah adalah mengerti, memahami serta menghayati secara mendalam terkait tugas serta kewajiban. Sifat yang demikian akan menumbuhkan daya kreativitas dan kemampuan diri dalam melakukan bermacam inovasi. Daya kreatif dan inovatif akan berkembang ketika seorang selalu berupaya untuk mengkaji beragam ilmu pengetahuan, dan informasi, baik yang berkaitan dengan dunia pekerjaan ataupun perusahaan secara umum sebagaimana dalam Surat Yusuf:55.

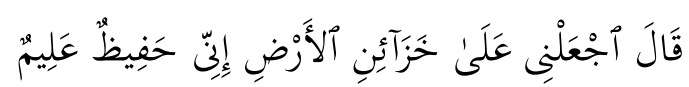

Artinya: Berkata Yusuf: "Jadikanlah aku bendaharawan negara (Mesir); Sesungguhnya aku adalah orang yang pandai menjaga, lagi berpengetahuan".

d. Amanah, mempunyai arti mempunyai tanggung jawab dalam menjalankan tugas dan kewajiban. Amanah digambarkan dalam bentuk keterbukaan, kejujuran, kesungguhan dalam melayani, dan melakukan yang terbaik dalam segala perbuatan. Sifat ini harus dimiliki dan dijiwai oleh seorang mukmin, 
khususnya bagi memiliki pekerjaan yang berkaitan dangan pelayanan kepada masyarakat. An-Nisa': 58.

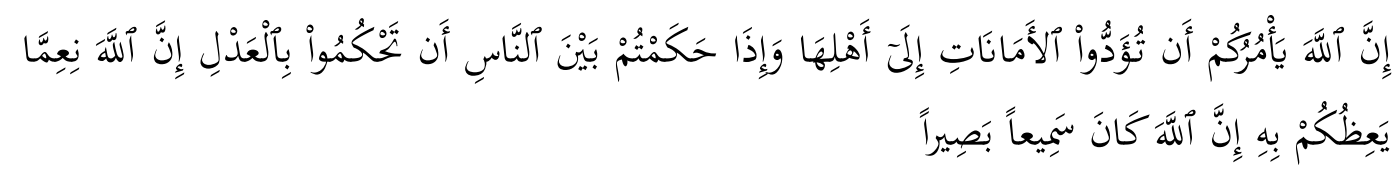

Artinya: "Sesungguhnya Allah menyuruh kamu menyampaikan amanat kepada yang berhak menerimanya, dan (menyuruh kamu) apabila menetapkan hukum di antara manusia supaya kamu menetapkan dengan adil. Sesungguhnya Allah memberi pengajaran yang sebaikbaiknya kepadamu. Sesungguhnya Allah adalah Maha mendengar lagi Maha melihat."

e. Istiqomah, adalah sifat konsisten dalam iman serta nilai-nilai yang baik walaupun dalam kondisi apapun. Istiqomah dalam perkataan dan perbuatan diwujudkakn dalam bentuk keteguhan, kesabaran, dan keuletan, sehingga kemudian akan menghasilkan kinerja yang optimal. Istiqomah merupakan buah dan hasil dari proses yang dikerjakan secara konsisten. Sebagi contoh, interaksi ibadah yang erat dengan Allah yang dilakukan seperti shalat, membaca Al-Qur'an, zikir, dan lainnya. Semua makenisme dan proses tersebut tentunya akan menghasilkan kebaikan dan kejujuran. Sebaliknya, keburukan serta ketidakjujuran tentunya akan tereduksi serta ternafikan secara nyata. Individu ataupun lembaga yang melambangkan sifat istiqomah akan menghasilkan ketenangan serta mendatangkan solusi serta jalan keluar terhadap persoalan yang dihadapi.

Secara teknis budaya yang diwarnai dengan sifat-sifat diatas akan menghasilkan produkivitas yang tinggi dalam sebuah perusahaan. Produktivitas pada hakekatnya merupakan sikap mental yang mempunyai persepsi bahwa "kehidupan yang dijalani hari ini harus lebih baik dari pada hari kemarin dan tentuya hari esok lebih baik dari hari ini.

Dengan sikap yang seperti diatas akan membuat seseorang selalu berupaya untuk mencari kebaikan-kebaikan serta peningkatan mutu dan kualitas hidup. Ciri tersebut menjadikan individu terus terdorong menjadi lebih dinamis, terbuka dan inovatif, dan lebih kritis terhadap perubahan-perubahan serta ide-ide. Dengan demikian produktivitas mempunyai pengertian sebagai sikap mental yang selalu berpandangan bahwa mutu kehidupan ini harus lebih baik dari hari kemarin dan hari esok harus lebih baik dari hari ini Sehingga dari beberapa pengertian diatas, maka penulis mengambil kesimpulan bahwa produktivitas kerja adalah kemampuan menghasilkan barang dan jasa dari berbagai sumberdaya atau faktor produksi yang digunakan dengan membandingkan hasil yang diperoleh dengan waktu yang telah ditentukan dengan adanya peran serta tenaga kerja atau karyawan. Definisi produktivitas pada kajian ini difokuskan pada kinerja

\footnotetext{
${ }^{8}$ Didin Hafiduddin,dkk, 2003, Manajemen Syariah, Jakarta: Gema Insani, hal. 32.
} 
dimana pengukurannya melalui penilaian kerja/hasil kinerja. Hal ini demkian dikarenakan kinerja juga mengandung makna prestasi kerja, pelaksanaan kerja, pencapaian kerja atau hasil kerja, penampilan kerja. Dimana kinerja mempunyai hubungan erat terkait masalah produktivitas, karena ia merupakan salah satu indikator untuk menentukan bagaimana usaha untuk mencapai tingkat produktivitas yang tinggi dalam suatu organisasi.

Beberapa faktor yang mempengaruhi Produktivitas Kerja dalam mencapai tingkat produktivitas yang tinggi, suatu perusahaan dalam proses produksi tidak hanya membutuhkan bahan baku dan tenagakerja saja, tapi juga harus didukung faktor-faktor lainnya. Antara lain adalah :
a. Pendidikan
b. Pelatihan
c. Penilaian prestasi kerja ${ }^{9}$
d. Sistem imbalan.
e. Motivasi.
f. Kepusan kerja

Mencermati pembahasan di atas dapatlah kita temukan bahwa Islam melalu kajian Ekonomi Syariah telah memberikan konsep dalam budaya kerja dengan beberapa sifat dan karekter diantaranya:

a. Al Shalah, mengandung arti kebaikan atau manfaat. Sebagaimana dalam Al Quran Surah An Nahl ayat 97:

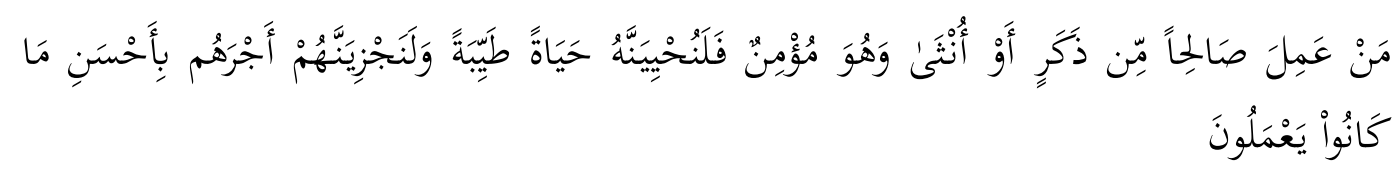

Artinya: "Barangsiapa yang mengerjakan amal saleh, baik laki-laki maupun perempuan dalam Keadaan beriman, Maka Sesungguhnya akan Kami berikan kepadanya kehidupan yang baik dan Sesungguhnya akan Kami beri Balasan kepada mereka dengan pahala yang lebih baik dari apa yang telah mereka kerjakan."

Ditekankan dalam ayat ini bahwa laki-laki dan perempuan dalam Islam mendapat pahala yang sama dan bahwa amal saleh harus disertai iman.

b. Al Itqan, mempunyai makna kemantapan/kesempurnaan atau perfectness

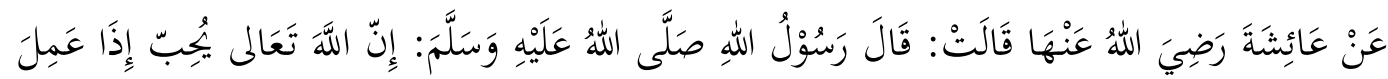

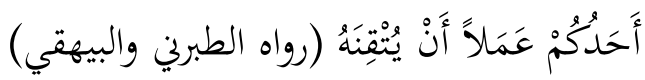

\footnotetext{
${ }^{9}$ Veithzal Rivai Zainal,dkk, 2009, Islamic Human Capital Manajemen (Cara Cepat dan Mudah dalam Menerapkan Manajemen Sumber Daya Insani dalam Perusahaan Secara Islami), Jakarta: Raja Garafindo Persada, hal.445.
} 
Artinya: "Sesungguhnya Allah SWT mencinyai jika seseorang melakukan sesuatu pekerjaan yang dilakukannya dengan Itqan/ sempurna (profesional)." HR. Thabrani dan Baihaqi.

c. Al Ihsan, adalah melakukan yang terbaik dan terus berupaya melakukan yang terbaik. Kualitas disini mempunyai dua makna yaitu:

1. Melakukan yang tebaik sesuai dengan kemampuan/ yang dapat dilakukan. Sebagaimana dalam pengertian Itqan.

2. Lebih baik dari prestasi atau kualitas sebelumnya. Dengan kata lain berusaha untuk melakukan peningkatan kuliatas. Baik dengan menambah pengetahuan baik untuk diri sendiri maupun untuk orang lain dalam makna dakwah.

d. Al Mujahada, usaha kerja keras atau optimalisasi, sebagaimana dalam Al Quran Surah Al Ankabuut Ayat 69:

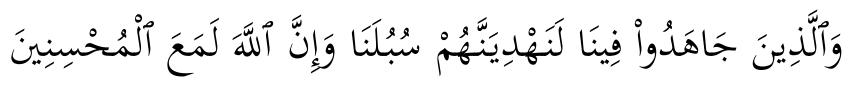

Artinya: "Dan orang-orang yang berjihad untuk (mencari keridhaan) Kami, benar- benar akan Kami tunjukkan kepada mereka jalan-jalan kami. dan Sesungguhnya Allah benar-benar beserta orang-orang yang berbuat baik."

e. Tanfus dan Taawun yang mempunyai makna berkompetisi dan tolong menolong. Sebagiaman dalam Al Quran Surah Al Maidah Ayat 2:

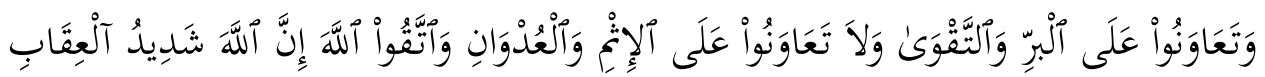

Artinya: "Dan tolong-menolonglah kamu dalam (mengerjakan) kebajikan dan takwa, dan jangan tolong-menolong dalam berbuat dosa dan pelanggaran. dan bertakwalah kamu kepada Allah, Sesungguhnya Allah Amat berat siksa-Nya."

Perubahan dalam karakter budaya yang dibangun pada saat seseorang sebelum bekeraja khususnya budaya bawaan dari luar lingkungan peruhaan tentunya tidak terbawa kedalam ranah perusahaan. Kondisi demikian dalam teorinya disebut dengan profesional. Namun kondisi tersebut harus dipopok dengan beberapa karekter yang kuat sebagaimana penjelasan di atas. Oleh karena itu perusahaan harus berupaya secermat mungking mengkolaborasikan metode-metode sebagaimana yang telah Islam ajarkan dalam rangka mendayagunakan kinerja dalam rangka peningkatan mutu dan kualitas kerja.

\section{Penutup}

Budaya merupakan unsur yang secara tidak langsung melekat pada individu yang dikarenakan beberapa faktor internal dan eksternal. Ketika budaya tersebut sudah melekat dalam diri individu tentunya akan berdampak kepada apa yang dia lakukan 
terhadap lingkungan dimana dia berada. Khsusnya dalam kajian disini terkait dengan dunia kerja. Entitas budaya seharusnya bisa menyesuaikan dengan dimana ia bekerja. Proses tersebut tentunya memerlukan proses dan ketaatan dalam pembentukan budaya kerja yang profesional. Oleh karena itu faktor internal individu sangatlah berpengaruh dalam pengolahan diri secara profesional tersebut. Dalam konteks Ekonomi Islam ada beberapa karakter dasar yang dapat menjadi acuan dalam proses pengembangan katekter budaya kerja. Diaman karakter tersebut meliputi al-Shalah, al-Itqan, al-Ihsan, al-Mujahada, Tanfus. Kreteria tersebut tentunya harus menjadi pusat perhatian dalam proses pembentukan individu dalam budaya kerja baik dari proses pembuatan visi, misi dan tujuan perusahaan sampai kepada proses perekturan tenaga kerja.

\section{DAFTAR PUSTAKA}

Hafiduddin, Didin, dkk, 2003, Manajemen Syariah, Jakarta: Gema Insani.

https://tafsirq.com/13-ar-rad/ayat-11\#tafsir-quraish-shihab

Nankervis, Alan R., 1996, Strategic Human Resource Manajemen, Melbourne: Nelson.

P Tilaar, H.A., 1997, Pengembangan Sumberdaya Manusia Dalam Era Globalisasi:Visi, Misi dan Proggram Aksi Pendidikan dan Pelatihan Menuju 2020, Jakarta :Grasindo.

Qardhawi, Yusuf Al, 2006, Pesan Nilai dan moral dalam Perekonomian Islam, Jakarta: Robbani Press.

Robins,Stepen, 1999, Perilaku Organisasi, Konsep, Kontroversi, Aplikasi, Alih Bahasa Hadyan Pujatmika, Jakarta: PT.Prenhallindo.

Sutrisno, Edy, 2010, Budaya Organisasi, Jakarta: Prenamedia Grup.

Zainal, Veithzal Rivai,dkk, 2009, Islamic Human Capital Manajemen (Cara Cepat dan Mudah dalam Menerapkan Manajemen Sumber Daya Insani dalam Perusahaan Secara Islami), Jakarta: Raja Garafindo Persada. 